\title{
FACTORS AFFECTING FOOD SECURITY OF RURAL FARMERS IN LESOTHO: THE CASE OF KEYHOLE GARDENERS IN LERIBE DISTRICT
}

\author{
Brian Muroyiwa $^{\bowtie 1}$, Linakane Theresia Ts'elisang ${ }^{1}$ \\ ${ }^{1}$ National University of Lesotho, Lesotho
}

\begin{abstract}
The practice of homestead vegetable gardening has gained importance due to the increasing rate of rural poverty in developing countries. Keyhole garden is not yet a particularly common variant of home gardens but it is becoming popular globally in both developing and developed countries due to its unique benefits related to sustainable farming practices. The main objective of the study is to determine factors that influence the food security of rural farmers in Lesotho utilising keyhole gardeners in Leribe district in Lesotho. The study used a purposive sampling method to select a sample of 110 respondents. Descriptive statistics and binary logistic regression models were used for data analysis. The majority of households $(65.45 \%)$ never skipped a meal and were food secure however, $27.27 \%$ sometimes skipped meals, and $7 \%$ skipped meals frequently. The study findings indicated that keyhole gardens influence food security since they boost food supplies, generate income and help in the reduction of food bills. The results of the study showed that age $(p<0.01)$, marital status $p<0.05)$, household size $(p<0.10)$, market information $(p<0.05)$, donations $(p<0.01)$ and access to inputs $(p<0.01)$ influence the food security of keyhole garden farmers in the study area. The study recommends that agriculture civil service workers should receive training on keyhole gardens so that they can transfer the knowledge and skills to rural farmers to increase the awareness of, and the participation in, keyhole gardening and ultimately influence household food security.
\end{abstract}

Keywords: keyhole garden, sustainable agriculture, food security, rural communities

\section{INTRODUCTION}

The Sustainable Development Goals (SDGs) of the United Nations Development Plan (UNDP), specifically objective number 2 , aim to end hunger, achieve food security and improve nutrition and promote sustainable agriculture (FAO, 2010; 2013). The challenge facing many countries across the globe is to increase food production towards meeting the food needs of their people, food security, safety, quality and nutritional requirements. Climate change poses a major risk to food security globally due to the reduction of yield of major crops (Olesen and Bindi, 2002; Parry et al., 2004). Countries need to adopt farming practices that conserve the limited water resources in areas that are getting dry to ensure adequate food production. Keyhole garden is one such concept that has been tried and tested globally. Although keyhole vegetable gardens are viewed as subsistence low-production systems, they can be structured to be more efficient commercial enterprises by growing high-value crops (Ranasinghe, 2009). FAO (2015) asserts that Lesotho faces challenges related to nutrition with around $33.2 \%$ of children under five years of age stunted (Kingdom of Lesotho, 2018). It is therefore not surprising that the government of Lesotho has pursued efforts to increase access to food for its citizens, especially for the most vulnerable ones, to ensure food and nutritional security. Innovations and technologies that

\footnotetext{
$\bowtie$ Department of Agricultural Economics and Extension, The National University of Lesotho, P.O. Roma 180, Maseru 100, Lesotho, e-mail: b.muroyiwa@nul.ls, https://orcid.org/0000-0001-7406-7636
} 
can reduce the devastating effects of drought and harsh climatic conditions are a necessity in the semi-arid areas of Lesotho. Due to the high incidence of drought in Lesotho, some farmers quit farming due to a lack of resources to cope and adapt. It is crucial that rural farmers understand and adopt conservation and sustainable agriculture practices to ensure food security in their communities.

In developed countries, most food production is in farms and in a non-urban setting, however, the situation is different in the least developed African countries. Similar to many least developed countries, agriculture is the major source of livelihood in the rural Lesotho. Nontertiary activities such as agriculture dominate economic activity, and occupations such as farming are the main sources of livelihood for the majority of the population in the least developed countries. Lesotho population is predominantly rural with around $70 \%$ of the population residing in rural areas (Rocchi and Sette, 2016). The rural population depends to a large extent on farming as the main source of livelihood and about $90 \%$ of these farmers are subsistence farmers (Rocchi and Sette, 2016). While the concept of keyhole gardens in the developed countries such as America and the United Kingdom is regarded mainly as an avenue to meet environmental awareness demands such as sustainable agriculture practices, in less developed countries such initiatives have been introduced by non-governmental organisations as a livelihood strategy. Similar to developed countries, keyhole gardens are a pathway to healthier food and health benefits for individual members who participate in keyhole gardening in developing countries. Keyhole gardens are popular with international development and permaculture practitioners and there have been successful tests in both developed and developing countries.

Communities located in rural areas in the least developed countries are very vulnerable to climate change shocks since they are largely dependent on income from farming which is seasonal. The inability to access enough nutritious food for an 'active and healthy life at all times,' results in food insecurity. In Lesotho, food insecurity is typically associated with hunger resulting from protein-energy malnutrition and micronutrient malnutrition. Keyhole gardens have the potential to increase access to nutritious food which is important as it contributes to a healthy and nutritious diet. Keyhole vegetable gardens are widely promoted in many poor countries as a mechanism to reduce poverty and as a source of income for subsistence farming families in developing countries.

In the past, the government of Lesotho introduced the concept of community gardens through non-governmental organisations. The government failed to realise the perceived benefits in the targeted communities since there were numerous challenges in terms of ensuring sustainable management of these community gardens (Mashinini, 2001). There are still some operational community gardens in Lesotho but the concept has not been successful due to the challenges affecting their optimum operation. The development of a model that could work in the Lesotho environment became an issue of paramount importance. Non-Governmental Organisations (NGOs) have successfully experimented with the concept of keyhole gardens elsewhere to fight poverty and hunger. The donor community piloted the concept in Lesotho; however, there is a dearth of literature on Lesotho and other countries, such as Uganda, where donor agencies have funded such initiatives. Villagers receive training as well as inputs and they work together in building the gardens. Keyhole gardening has assisted in dealing with the conflicts that previously surrounded the land tenure and allocation issues (Mashinini, 2001) which made the community garden concept unsustainable in Lesotho. The communities are now practising keyhole gardening and it is important to interrogate whether the perceived benefits, which include food security through the access and availability pillars, are being realised. This study seeks to fill that gap in the literature and provide evidence of whether keyhole gardens have contributed successfully to the food security of the Basotho people involved in the initiative. Evidence of the effectiveness of the contribution of keyhole gardens to the food security of vulnerable households is scarce.

Small-scale homestead food production programmes aimed at increasing access to nutritious foods have been found to support livelihoods and food security and are proposed as potentially useful platforms for delivering nutrition-specific interventions targeted to women and young children (Ruel and Alderman, 2013). Evidence of the effectiveness of these programmes in improving nutrition outcomes, however, is scarce, in part due to poor programme and evaluation designs as noted in several reviews (Girard et al., 2012; Masset et al., 2012). The aim of this study is to identify and describe factors that influence the food security of rural farmers in Lesotho. The study focuses on keyhole garden farmers in 
Lesotho, and the decision was influenced by the need for smallholder farmers to adopt to climate change through embracing Climate Smart Agriculture (CSA) practices.

\section{THEORETICAL ISSUES}

\section{Home Gardens}

Improved household dietary patterns and better nutrition of individual household members have been linked with household or farm-level agricultural production (Carletto et al., 2015). An extensive literature exists evaluating these linkages and focussing on three key pathways linking food production and nutrition: income from agriculture, a household's consumption of its own produce and gender dimensions (Carletto et al., 2015). This study assumed that households produce beyond their own consumption levels to market the surplus and thus supplement their income. The household would use the supplementary income to increase its dietary diversity. Global and domestic food prices continue to rise due to an unstable global economic environment and uncertainty. Lesotho depends on its neighbour South Africa for the bulk of its food import needs, and the increases in value-added tax in South Africa directly affect the Lesotho population. The major challenge in Lesotho, unlike South Africa, is the absence of safety nets for the most vulnerable through the availability of zero-rated food items.

Low-income households, especially those in rural areas, would find it difficult to access certain food items and there is a need to offer innovative ways for them to supplement incomes and produce other food outputs using affordable and readily available means. Marginalised and food-insecure groups are more severely affected by higher food prices than other segments of the society, higher food prices reduce purchasing power and negatively affectg food consumption (Quisumbing et al., 2008). Some farmers in rural areas are able to feed their families and generate a household income without encroaching on marginal land or depending on chemical fertilisers. Haselow et al. (2016) assert that reviews of home gardening programmes have noted poor intake in water-constrained villages or dry seasons since fruit and vegetables are typically water-intensive crops. This has compromised production, food security and return on farmer investment resulting in some farmers abandoning farming altogether. Much of sub-Saharan Africa is water-scarce and small-scale irrigation is scarce (You et al., 2015), lessons that have been learnt from keyhole gardens can therefore be directly exportable to other water-scarce areas. Direct exportation of the keyhole garden concept is necessary since much of the region is vulnerable to drier conditions due to climate change (Giannini et al., 2008). The keyhole garden concept has been used in African countries such as Ethiopia, Ghana, Lesotho, Burkina Faso, Niger and Rwanda with very encouraging results. Figure 1 below shows the conceptual framework of the study.

\section{CONCEPTUAL FRAMEWORK}

The conceptual framework illustrated in Figure 1 demonstrates that conservation agriculture practices, such as keyhole gardens, had an effect on food security and improved livelihoods through the income they generated. Households that are organised into savings groups have the potential of running successful savings schemes through income generated from their gardening activities. Keyhole gardens have the potential to provide yearround produce, with benefits such as watering with the use of recycled water that reduces competition in the use this scarce resource, especially in dry areas. Keyhole gardeners are organic farmers, they use manure and composting and these farming practices are environment-friendly and preserve soils. The assumption is that the income generated from farming activities would improve the livelihood of farmers, ultimately positively influencing households' food security status. Food-secure households, especially vulnerable groups that have keyhole gardens, achieve improved health and nutrition outcomes.

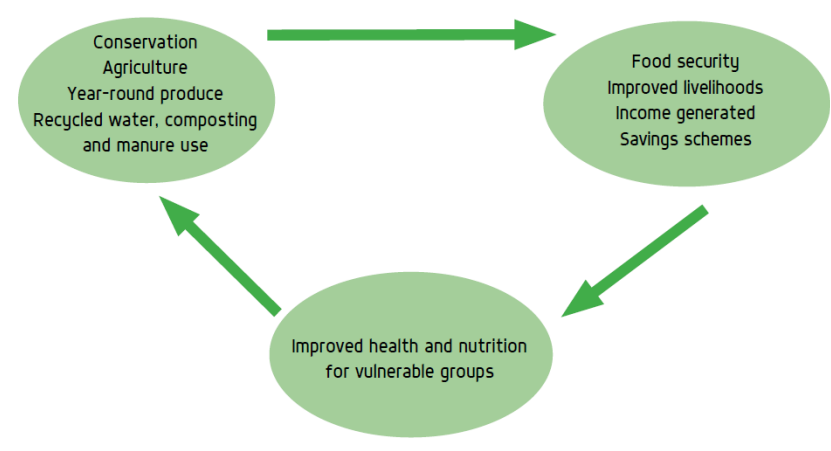

Fig. 1. Conceptual framework Source: Billingsley et al., 2013. 


\section{Growing sustainable and resilient agriculture: keyhole gardens}

Global efforts for decades have been towards increasing agricultural growth, which in itself does not necessarily lead to improved nutrition but possibly to increased food production and availability. Growth in the agricultural sector using sustainable farming practices is necessary due to the need to feed a growing world population. The focus of UN agencies, donors and governments had to shift towards promoting home gardens to achieve better family nutrition, and this largely has yielded positive results (FAO, 2015; 2018). The keyhole garden is a concept that originated in Africa, developed through the initiative of the Consortium for Southern Africa Food Security Emergency (C-SAFE). The basis of the design for the keyhole garden originated from CARE in Zimbabwe. C-SAFE is a project led by international nongovernmental organisations (NGOs) such as Care, the Catholic Relief Services (CRS) and World Vision (Billingsley et al., 2013). At inception, the keyhole garden initiative was targeted at assisting the most vulnerable households affected by HIV/ AIDS, especially households with elderly or chronically ill people and with orphaned children (Billingsley et al., 2013). However, keyhole gardens have grown in popularity, they have replicated the effects obtained in Arizona and Texas in the United States. The concept of a keyhole garden can thrive in drought-prone areas since such gardens have high moisture retention and require less frequent watering. Keyhole gardens have proven an effective way to grow vegetables all year round in semi-arid climates with poor soils because they nourish the soil and help retain moisture. The promotion of keyhole gardens in Lesotho among populations vulnerable to hunger and food insecurity by C-SAFE was a strategy to improve the resilience of households to external shocks such as drought. NGOs and donors have modified keyhole gardens to expand their size since they were initially too small to contribute meaningfully to household food security.

A keyhole garden is a drought-resistant, sustainable, high-yield, low-maintenance gardening system developed in Africa. Keyhole gardens also use greywater because of their structure that prevents the water from harming the plants. This is of significant importance since water is a scarce resource and the ability to conserve water as well as reuse waste (grey) water while enabling year-round diversity of vegetables provides an effective and sustainable food production system for poor vulnerable rural households. Scarcity of water and aridity are among the main challenges that discourage rural dwellers from practising and expanding home gardening, especially in the arid and semi-arid parts of SubSaharan Africa (SSA).

\section{MATERIALS AND METHODS}

\section{Description of the study area}

The study area was located in the Leribe district in the northeastern part of the country. In the north the Leribe district borders with the Botha-Bothe district, in the east, with the Mokhotlong district and in the south, with the Berea and Thaba-Tseka districts. The western part of the district is at the border with South Africa. The Leribe district covers 282,810 hectares or $9.32 \%$ of the country's area. As far as the country's topography is concerned, it consists of $42 \%$ of lowlands (below 1,800 $\mathrm{m}$ ), $28 \%$ of foothills (between $1,800 \mathrm{~m}-2,300 \mathrm{~m}$ ) and $30 \%$ of mountain areas (above 2,300 m). Most of this area is not arable but it is suitable for livestock grazing. In 2016 Leribe district had a population of 337,500 people. Its capital town is Hlotse. The livelihood of people in Leribe depends on agriculture because most villagers engage in crop and animal production with few people engaged in full-time formal employment.

\section{Sample design and data collection}

The study used primary data; the process of collecting data from participants in the study area involved soliciting information on factors that influence their food security status. Although agriculture is the main source of livelihood in the study area, keyhole gardening is not practised universally. There are farmers who participate in keyhole gardens, while others do not participate, therefore a purposive sampling technique was used to identify the target population of interest to select the sample for the study. Purposive sampling is a non-probability sampling approach that concentrates on people with particular characteristics who will be able better to assist with the relevant information based on the objective of the study. The study sample was selected from four rural villages in the district of Leribe. From three of the villages (Metolong, Ha Mohale and Malibamatso) 30 participants were selected for each village, and 20 individuals were selected from the Metolong village, 


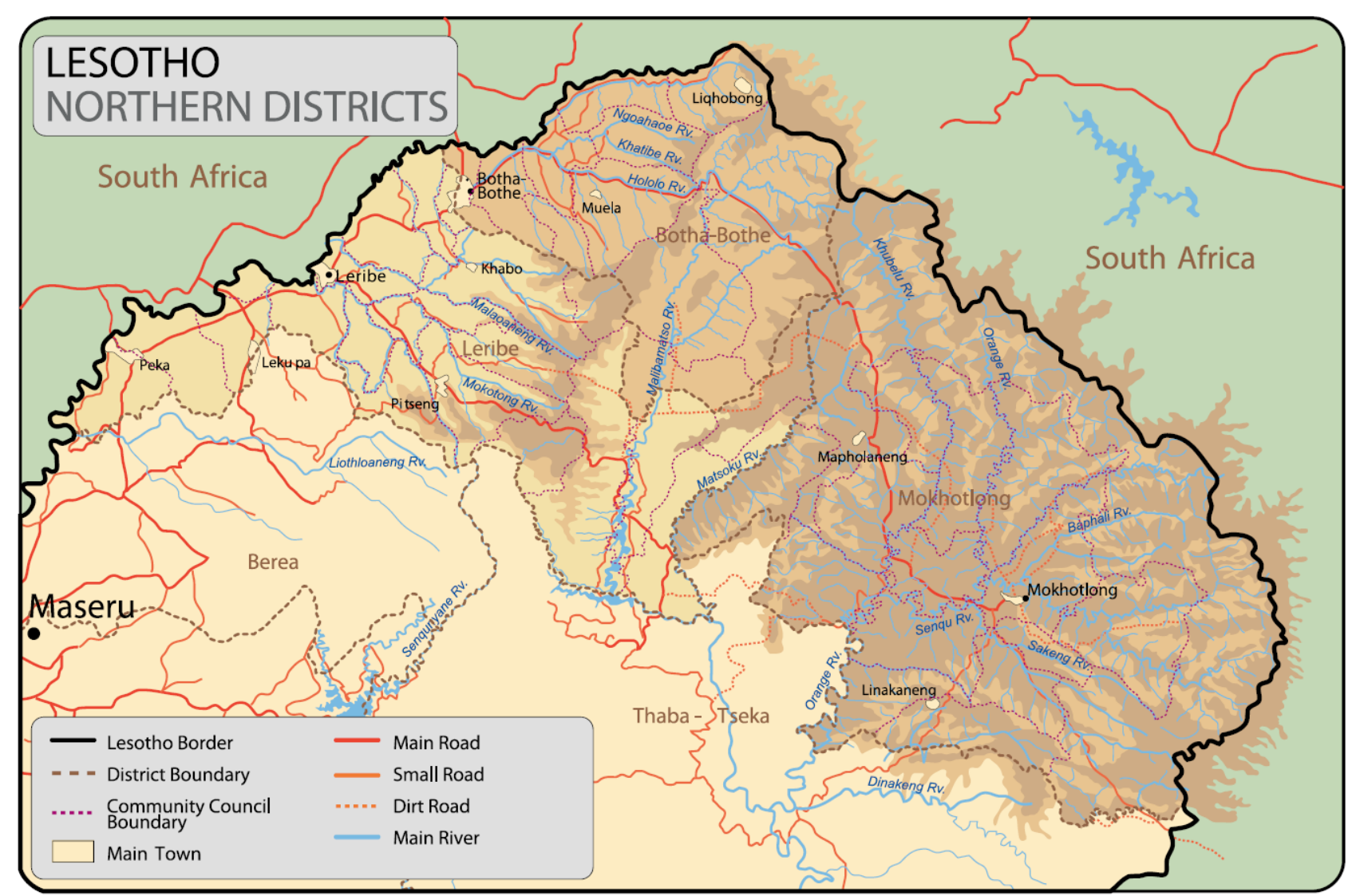

Fig. 2. Map of the study area

Source: UNOCHA, 2014.

which comprises the total sample size of hundred and ten farmers for the study. The data were collected using a questionnaire with close-ended questions. One hundred and ten (110) questionnaires were filled in by the respondents. The questionnaire was translated into the local language Sesotho to enable all the respondents to understand the questions, which would improve the quality of responses.

\section{Descriptive Statistics and the Binary logistic regression model}

The study used descriptive statistics to analyse, describe and profile the socio-demographics of the respondents. The logit model was used to identify the socio-economic factors that influence the food security of keyhole garden farmers through the access pillar. The study used income as the dependent variable since most households are entirely dependent on agriculture. Food access was measured using income since income received by households from selling their produce possibly caters for other household food needs.

The study utilised the binary logistic regression model to analyse the factors that contribute to food security (access) amongst keyhole garden participants using the functional form of logit model expressed by Gujarati (2004) as:

$$
P_{i}=\frac{1}{1+e x_{i}}
$$

For simplicity equation 1, the expression is as follows:

$$
P_{i}=\frac{1}{1+e^{-z i}}
$$

Where $P_{i}$ is the probability of food security (access) of the $i^{\text {th }}$ respondent, $e^{-z i}$ stands for the irrational number raised to the power of $Z_{i}$. $Z_{i}$ is a function of $\mathrm{N}$ explanatory variables and is expressed as: 
Table 1. Explanatory variables, description and the expected outcome

\begin{tabular}{|c|c|c|c|}
\hline Variable & Description and measurement type & Variable type & Expected outcome $(+/-)$ \\
\hline Age & Age of farmer (years) & continuous & + \\
\hline Gender & Gender of farmer $(1=$ female $0=$ male $)$ & dummy & + \\
\hline Education level & Farmer's education level & continous & + \\
\hline Marital status & $\begin{array}{l}\text { Marital status of farmer }(0=\text { Single, } 1=\text { Married, } 2= \\
\text { Widowed })\end{array}$ & continuous & + \\
\hline Household size & Farmer's household size & continuous & + \\
\hline Off-farm oncome & Farmer's other Sources of Income $($ Yes $=1$, No $=0)$ & dummy & + \\
\hline Market Information & Access to market information $(\mathrm{Yes}=1, \mathrm{No}=0)$ & dummy & + \\
\hline Access to Input & Access to agricultural input $\left(Y e s=1, N_{0}=0\right)$ & dummy & + \\
\hline Donations & Access to agricultural donations $(\mathrm{Yes}=1 ; \mathrm{No}=0)$ & dummy & + \\
\hline
\end{tabular}

+/- indicates a positive or negative relationship with the dependent variable.

Source: own elaboration.

$$
Z_{i}=B_{0}+B_{1} x_{1}+B_{2} x_{2}+\ldots+B_{n} x_{n}+\mu_{\mathrm{i}}
$$

Where $B_{0}$ is a constant term, $B_{0}, \ldots, B_{n}$ are regression coefficients. Therefore,

$$
\begin{gathered}
Z_{i}=B_{0}+B_{1}(\mathrm{AGE})+B_{2} \text { GENDER }+B_{3} \text { MARSTATUS }+ \\
B_{4} \text { HHSIZE }+B_{5} \text { OFFFARMY }+B_{6} M \text { KIINFO }+(4) \\
B_{6} \text { ACCINPUTS }+B_{6} \text { DON } \ldots+\mu_{i}
\end{gathered}
$$

The dependent variable of income is a dichotomous variable where the farmers had to choose between two options. The farmers had to indicate whether their income increased or decreased after they started participating in keyhole gardens.

\section{Independent Variables and Their Expected Outcomes}

The independent variables that were used in the study are presented in Table 1 and the choice of independent variables was guided by the literature. Table 1 shows the independent (explanatory) variables, their description and the expected outcome in relation to the dependent variable.

\section{RESULTS AND DISCUSSION}

\section{Farmers' demographics and socioeconomic characteristics}

The descriptive statistics presented in Table 2 show that the majority of keyhole garden participants are women accounting for $85 \%$ of the respondents. This is not surprising since, in the least developed countries, including the countries of SSA, homestead gardening is traditionally the responsibility of women. Women are the ones who participate more in the homestead garden because they usually take care of their families when men are at work (Awasthi and Bhat, 2016). Table 2 represents the age of the household head, $54.55 \%$ of the respondents are over fifty, $45.45 \%$ of the respondents are between 20 and 50. A household head is the household member who makes the decisions and coordinates activities of the household (Harris-Fry et al., 2015). Any family member regardless of his/her age can participate in homestead vegetable gardens and generate income (Mohsin et al., 2017).

Table 2 shows that most of the farmers, that is $95.6 \%$, have experience of more than a year in homestead vegetable garden, few of the sampled farmers (4.4\%) lack experience. Due to the time they spent in farming activities, farmers are able to solve daily challenges they meet and increase their productivity and farm income (Abbasi et al., 2014). Table 2 also presents the marital status of respondents with $60.5 \%$ married, $1.85 \%$ single, and $37.6 \%$ widowed. Marital status can be an indicator of responsibility level based on the results by Paudel et al. (2019) who maintain that married people are able to share household activities such as gardening. Marital status provides structured role and normative identities that are associated with a variety of behaviours (Ruben et al., 2017). 
Table 2. Farmers' demographic and socio-economic characteristics

\begin{tabular}{|c|c|c|c|}
\hline Variable & Class & Frequency & Percentage \\
\hline \multirow[t]{2}{*}{ Gender } & Male & 14 & 12.73 \\
\hline & Female & 96 & 87.27 \\
\hline \multirow[t]{2}{*}{ Age } & $20-50$ & 45.45 & 50 \\
\hline & 51 and above & 54.55 & 60 \\
\hline \multirow[t]{3}{*}{ Marital status } & Single & 2 & 1.83 \\
\hline & Married & 66 & 60.55 \\
\hline & Widowed & 41 & 37.61 \\
\hline \multirow{2}{*}{$\begin{array}{l}\text { Employment } \\
\text { status }\end{array}$} & Employed & 8 & 7.27 \\
\hline & Unemployed & 102 & 92.73 \\
\hline \multirow{3}{*}{$\begin{array}{l}\text { Household } \\
\text { size }\end{array}$} & 1 to 3 & 16 & 14.55 \\
\hline & 4 to 6 & 59 & 59.09 \\
\hline & $>7$ & 29 & 26.36 \\
\hline \multirow{4}{*}{$\begin{array}{l}\text { Level of } \\
\text { education }\end{array}$} & No formal education & 19 & 17.27 \\
\hline & Primary education & 62 & 56.36 \\
\hline & Secondary education & 27 & 24.55 \\
\hline & Tertiary education & 2 & 1.82 \\
\hline \multirow{2}{*}{$\begin{array}{l}\text { Employment } \\
\text { status }\end{array}$} & Unemployed & 102 & 92.73 \\
\hline & Formally employed & 8 & 7.27 \\
\hline \multirow[t]{2}{*}{ Health } & Improved & 108 & 98.18 \\
\hline & Not improved & 2 & 1.82 \\
\hline \multirow{4}{*}{$\begin{array}{l}\text { Type of veg- } \\
\text { etable grown }\end{array}$} & Turnip & 20 & 18.18 \\
\hline & Spinach & 61 & 55.45 \\
\hline & Beetroot and Carrots & 15 & 13.64 \\
\hline & Other & 14 & 12.73 \\
\hline \multirow{4}{*}{$\begin{array}{l}\text { Vegetable } \\
\text { intake }\end{array}$} & Several times a day & 103 & 93.64 \\
\hline & Once a day & 3 & 2.73 \\
\hline & Several times a week & 3 & 2.73 \\
\hline & Almost never & 1 & 0.91 \\
\hline \multirow{2}{*}{$\begin{array}{l}\text { Income } \\
\text { received from } \\
\text { the garden }\end{array}$} & Yes & 62 & 56.36 \\
\hline & No & 48 & 43.64 \\
\hline
\end{tabular}

Source: own elaboration.
Table 2 reveals that most farmers $(56.3 \%)$ had primary education, $24.5 \%$ had a high school level of education, $1.82 \%$ tertiary, and $17.27 \%$ non-formal education. Education is an important tool in imparting knowledge and skills that will enable individuals to function as economic change agents in their society (Bajwa et al., 2015). Most of the respondents did not have a high level of education but they participate in homestead gardens. Table 2 also shows the household size distribution of respondents in the study area. $14.55 \%$ of households have 1-3 members, followed by $55.1 \%$ having $4-6$ household members; and $23.36 \%$ with 7 and more household members. Manju and Bhawana (2014) found that the number of household members and working members capture the quantity of human capital and have important practical implications for labour availability that acts as the basis for a household to decide whether to practice in different activities. Nwaneke and Chude (2017) assert that children are an added labour advantage for increased agricultural productivity because they do many activities in the farm work. A higher number of children is an indication of family wealth in rural areas.

\section{Food accessibility of participants}

The percentage of homestead garden participants that have food to eat every day is $65.5 \%, 27.4 \%$ of participants sometimes skip meals because there is nothing to eat, $7.3 \%$ of the participants frequently skip meals because they have nothing to eat. Most of the participants reported eating regularly several times a day, and they have access to quality fresh vegetables. Allagbe et al. (2014) show that rural area households' access to food can be limited by financial constraints that force farmers to buy inputs necessary for production over immediate household food needs. Some rural residents and households are food insecure since they cannot rely on having access to sufficient affordable nutritious food at all the time (BOS, 2017).

Table 3. Access of rural farmers to food from vegetable homestead gardens

\begin{tabular}{lccc}
\hline \multicolumn{1}{c}{ Skip meals } & Frequency & Percentage & Cum. frequency \\
\hline Never & 72 & 65.45 & 65.45 \\
Sometimes & 30 & 27.37 & 92.73 \\
Frequently & 8 & 7.27 & 100 \\
\hline
\end{tabular}

Source: field survey, 2019. 


\section{Factors affecting the food security of} respondents: binary logistic regression

The study used binary logistic regression to identify the factors that influence the food security of the households that participated in the study. This section discusses the effect of the variables that the study included in the logistic regression model as informed by literature to have an influence on the food security status of the respondents. Each of the factors, that is age, marital status, gender, household size, education, employment status, nonfarm income, donations, farming experience, access to inputs and market information and their effects on food security are discussed in this section.

\section{Age}

The coefficient is significant at all levels of significance, therefore, age influences the food security of keyhole garden farmers. A year increase in age increases income from keyhole gardens by (0.0143) at a 5\% level of significance according to the results of this study. Age is an important factor in the determination of household food security status. The findings of a study by Abdullah et al. (2019) showed that household food insecurity varied significantly among different age groups. Households with older household heads were food secure and households with younger household heads were not food secure (Abdullah et al., 2019). There is a significant positive relationship between the age of the farmer and the contribution of a keyhole garden to food security. The results are consistent with previous studies; all these studies confirm that families with older household heads tend to be food secure. Gardening is largely practised by the physically fit, however, older farmers have adopted keyhole gardens due to the nature of the keyhole garden concept which makes gardening less laborious compared to conventional gardens. Keyhole gardens, therefore, become a significant source of livelihood since they contribute to the income of farmers and their food security status. Old and young farmers have the same chances of participating in keyhole vegetable gardens influencing capacity to generate income. Mohsin et al. (2017) argue that when a farmer becomes older, he/she becomes more food insecure as their participation in homestead gardens declines. This is contrary to the findings of this study that suggest a positive relationship between age and participation in keyhole gardens. Keyhole garden does not involve too much physical activity and this could explain why older farmers participated in keyhole gardening in this study.

Table 4. Estimates of the binary logit model

\begin{tabular}{|c|c|c|c|c|c|}
\hline Variable & Coefficients & Odds Ratio & Std. Err. & $z$ & $P>z$ \\
\hline Constant & -1.716 & 0.004 & 0.008 & -2.75 & 0.006 \\
\hline Gender & 0.004 & 0.677 & 0.278 & -0.95 & 0.343 \\
\hline Age & $0.0143 * * *$ & 1.067 & 0.026 & 2.64 & 0.008 \\
\hline Marital status & $0.649 * *$ & 1.214 & 0.113 & 2.09 & 0.037 \\
\hline Household size & $0.140^{*}$ & 0.762 & 0.115 & -1.81 & 0.071 \\
\hline Education & 0.184 & 1.101 & 0.2899 & 0.36 & 0.716 \\
\hline Employment status & 0.131 & 1.140 & 0.922 & 0.16 & 0.871 \\
\hline Farming experience & -0.134 & 0.875 & 0.657 & -0.20 & 0.839 \\
\hline Non-farm Income & -0.928 & 1.000 & 0.000 & 1.63 & 0.104 \\
\hline Market information & $3.684 * *$ & 6.762 & 5.091 & 2.54 & 0.011 \\
\hline Access to inputs & $2.501 *$ & 0.1318 & 0.681 & -2.81 & 0.005 \\
\hline Donations & $2.377 * * *$ & 0.060 & 0.055 & -3.06 & 0.002 \\
\hline
\end{tabular}

Source: own compilation. 


\section{Marital status}

The coefficient is positive and significant at a $5 \%$ level $(0.03)$ according to the results of the study, which means that marital status has a positive effect on the food security status of a rural household. A study by Maziya et al. (2017) also found that the marital status of the household head was significant. Contrary to Maziya et al. (2017), the coefficient is positive, however, it suggests the same conclusion as that reached by Maziya et al. (2017) that the households headed by married individuals have a high chance of becoming food secure. Although the coefficient of marital status is significant in both studies, in the study by Maziya et al. (2017) this coefficient was negative as they concluded that households headed by married individuals had a lower chance of becoming food insecure. This study considered food security status in the affirmative and reached the same conclusion - that households headed by married individuals had a high chance of being food secure, since the findings revealed a positive relationship. The high level of participation of females in keyhole gardens could explain this finding as marriage in the African rural context empowers women to access resources through their husbands. There is bias in resource ownership in favour of men in both urban and rural communities due to historical gender imbalances. In rural areas when men migrate for greener pastures, women have the access to, and the opportunity to control, homestead resources. Furthermore, in rural Africa, where some of the traditional roles and chores have not been eroded by westernisation, women are responsible for gardens and providing the favourite stiff pap common in most countries in Southern Africa. The production of vegetables in keyhole gardens makes it easier for rural married women to perform and fulfil their duties. Married farmers are responsible for taking care of their families, which is why these households need to increase vegetable production to satisfy household consumption whilst the surplus contributes to more farm income used for other family purposes (Vitiello and Wolf-Powers, 2014). This makes the household food-secure and, essentially for this study, the majority are females who are the most active members in gardening in African countries. The descriptive statistics in Table 2 show that the majority of respondents are either married or widowed. Gardening is a buffer for household food insecurity and a livelihood strategy for the poor and for vulnerable rural women, especially widows. In most cases, widows have children to look after and they are the sole breadwinners for those households.

\section{Household size}

The coefficient is significant at a $10 \%$ level of significance, which means that the size of the household affects the food security status of a household engaged in keyhole gardens. This concurs with findings by Amaza et al., 2006; Haile et al., 2005; Iorlamen et al., 2013 who demonstrated that the coefficient of household size is significant, which implies that household size is accountable for household food security status. These findings are consistent with an assertion by Rose and Charlton (2002) that the incidence of household food insecurity in South Africa increases with increasing household size. The findings of these studies imply, similar to the results of this study, that household size influences the food security of respondents. The conclusion reached based on the findings of this study is that although keyhole gardens can, (directly and indirectly) significantly contribute to the satisfaction of the food needs of the households used in the study sample, the threat to household food security status increases as household size increases. The explanation for this could be the challenge in the design of keyhole gardens that allows it a very limited space. Although keyhole gardens are not labour-intensive and any individual who is a member of a household can engage in keyhole gardens, the limited space is a huge constraint on the quantities produced. The larger the size of the family, the more the demand and strain it puts on the household's food security needs and the higher the chances of food insecurity. Bogale (2012) also asserts that the size of the family determines the food security status of a household.

\section{Gender}

The coefficient is positive and insignificant at levels of significance. This finding suggests that the gender of a keyhole garden farmer does not influence food security status. Therefore, gender does not affect a farm's income, the proxy for food security in this study, both males and females have the ability to generate income from keyhole gardens and hence become food secure. Taiwo (2015) asserts that both men and women can participate in homestead gardens and, as a result, accrue income. The anticipation is that the accrued income would enhance the satisfaction of other household food needs thus ensuring that the household is food-secure. Even though gardening is mostly the occupation of women, there is no evidence that there are gender barriers that affect participation. Since both men and women can freely 
engage in keyhole gardens, the coefficient for gender is insignificant at all levels of significance as being neither male nor female would influence participation and hence income from the keyhole garden enterprise. This is distinct from other studies that have found that the gender of the household head plays an important role in household food security status (Kassie et al., 2014). A study by Kassie et al. (2014) revealed that even if the household head could have the same visible characteristics, invisible qualities are responsible for the difference in food security level. A visible characteristic of the household head, such as their gender, plays a dominant role in food insecurity, as female-headed households were food insecure while male-headed households were food secure (Abdullah et al., 2019; Rose and Charlton, 2002). The findings of a study by Ibnouf (2011) contradict those findings suggesting that women, compared to men, are more likely to play a positive role in household food security, the latter group migrates seasonally, and sometimes permanently. This is largely the case in Lesotho where there is migration to the neighbouring South Africa in which case women have to manage household farming activities. This could explain why gender is insignificant in influencing food security in Lesotho unlike in the the results of the other study.

\section{Education}

Contrary to findings by Abdullah et al. (2019), Mango et al. (2017) and Maziya et al. (2017) who found that education is a significant determinant of food security, this study found education to be insignificant. The education level of the farmers has no influence on the contribution of keyhole gardens to food security. This is because the coefficient of the education level of farmers is insignificant at all levels of significance. The assumption is that people with higher levels of education are more likely to get higher-paying jobs and be more food secure. This would apply in urban areas were most people are educated. However, in rural areas in Africa where there are many dropouts at the primary and high school level, education becomes an insignificant factor. The advantage of the keyhole garden initiative is that the level of education is not the basis for participation. Keyhole garden farmers receive training from NGOs that equip them with knowledge and skills on how to tend to their gardens. Education status is therefore redundant as any farmer, regardless of their education level, can participate in keyhole gardens and generate income. The majority of the respondents $(73.6 \%)$ have been educated only up to the primary school level. Participation in homestead gardens does not require the farmer to be educated. Most of rural farmers are not educated, and nonetheless, they are able to produce vegetables for family consumption and generate income by selling the surplus. This is contrary to the findings by Oduro-Ofori et al. (2014) who discovered that education increases agricultural productivity primarily by improving farmers' ability to make decisions and by boosting their technical efficiency. Technical efficiency is meant here as the farmers' capability to make better choices in terms of input combinations and ability to make better, economically rational decisions.

\section{Employment status}

Different from Abdullah et al. (2019), employment status is insignificant at all levels, which implies that both employed and unemployed farmers have the ability to derive improved food security status for their households from keyhole gardening. In the study by Abdullah (2019), unemployed people were food-insecure and vice versa,. The majority of respondents in this study are unemployed and this is the case in most parts of rural Africa. The main source of livelihood is farming, especially for people from poor backgrounds where other income-generating activities do not exist. In other instances, farming is the only skill that individuals have, and they are not able to compete for other jobs that need a particular set of skills and qualifications. Other studies indicate that employed farmers have less time than unemployed farmers for tending to their gardens. Unemployed farmers spend most of their quality time in gardens (Hernandez et al., 2010). Since anyone regardless of their employment status can participate in keyhole gardens, employment status is insignificant in influencing the food security status of the households in Leribe that participate in keyhole gardens. However, since farming is their main occupation, it is the main contributor to household food security status.

\section{Farming Experience}

Farming experience is insignificant at all levels of significance, implying that farming experience does not have impact on farmers' household food security status. Maziya et al. (2017) found that farming experience is statistically significant and negatively related to food insecurity, contrary to the findings of this study. 
Households headed by older people are thus more likely to be food-secure than those with younger heads. Older, more experienced farmers tend to have more food in their households compared to younger inexperienced farmers. The assumption is that the element of farming experience and knowledge gained with age enables the household to spread the risks of food insecurity through strategies such as diversified production (Twongyirwe et al., 2019). Farming experience improves a farmer's farming skills and improves the chances of achieving a good livelihood. The study findings show that a farmer, with or without experience, can improve their food security status by participation in keyhole gardens. This is contrary to the findings by Ruben et al. (2017) who claimed that farming experience can increase farm income generated by farmers because they have practised farming activities for a long time, therefore they would be able to improve their productivity and solve their daily challenges. Keyhole gardens are simple to manage because farmers receive training from NGOs, which could explain the findings of this study. A keyhole gardener does not necessarily need farming experience to practice keyhole gardening successfully.

\section{Off-farm income}

The coefficient of off-farm income is insignificant at all levels of significance; hence, off-farm income does not have an impact on the food security status of a household practising keyhole gardening in Leribe. The respondents indicated that they receive donations from the government and NGOs. These donations are in the form of farming inputs, thus any household with or without off-farm income has the ability to participate in keyhole vegetable gardens, which would contribute to household food security. This is contrary to the findings by Hernandez et al. (2010) who found the coefficient of off-income to be significant and claimed that off-farm income helps the farmer buy inputs necessary for production when the farm is not generating any income. The assumption is that off-farm income would increase the income of the household; therefore, decreasing household income is associated with the incidence of food insecurity and vice-versa. Additional income is generally utilised to purchase additional food items, further increasing the diversification of the household diet (Roy et al., 2013). Lesotho used to have a significant number of expatriate workers, especially in South African mines. Remittances were always an important source of income and external financing for many poor rural households in Lesotho. However, the number of expatriates originating from Lesotho has declined over the years since mines in South Africa have been shutting down. In the study area, the respondents did not receive any remittances, which could possibly explain the insignificance of off-farm income. Abdullah et al. (2019) find remittances to be significant and positively influence food security status of households that receive remittances.

\section{Market information}

The coefficient is significant at all levels of significance, meaning that market information has a positive impact on farm income and the food security status of a rural farming household. This is similar to the findings of a study by Mango et al. (2014) revealing that access to market information influences household dietary diversity. The results also conform to the findings by Nyikahadzoi et al. (2012) who show that access to market information has a positive influence on a household's dietary diversity and a negative influence on food insecurity. Alene et al. (2008) stated that access to market information is the main factor inducing market participation. Households that can meaningfully participate in markets are likely to get higher cash incomes which they can use to buy diversified and even preferred foodstuffs. An increase in access to market information by the farmer will result in an increase in farm income. It is important for the farmer to have information about where he/she has to market the produce (Suvedi et al., 2017). The government should also place more emphasis on monitoring and evaluating vegetable markets to protect farmers from potential 'parasitic' intermediaries in vegetable markets (Paudel et al., 2019).

\section{Donations}

The coefficient is significant at all levels of significance. Input donations increase the odds of being food-secure for a household engaged in keyhole gardening. An increase in input donations results in an increase in farm income since farmers are able to produce and market surplus produce. Most of the farmers in the study area receive from NGO's donations of inputs, such as seeds, hand forks, watering cans and others. The availability of input donations is important for rural farmers, especially those receiving low income, to help them alleviate hunger and poverty, , but most farmers do not want 
to do things for themselves even though they have the ability to buy inputs for themselves; they always want to receive donations (Jha et al., 2016). This is common in most African communities that suffer from the 'donor dependency syndrome'. Maziya et al. (2017) found that the receipt of social grants is statistically significant and negative implying that households that receive social grants are less prone to food insecurity. Donations and social grants form part of social security; donations come in the form of inputs and food parcels, while grants can be useful for buying food.

\section{Access to Inputs}

The coefficient is significant at all levels of significance. There is a positive relationship between increased access to inputs and keyhole garden productivity that in turn increases farm income and the chances of being foodsecure. Unavailability of inputs to rural farmers leads to a decline in the productivity of homestead gardens. Rural areas in most parts of Africa lack the presence of viable agribusiness firms that would guarantee ready availability of affordable inputs to farmers without travelling long distances (Paudel et al., 2019). Inputs are not readily available in rural areas; furthermore, farmers usually struggle with income to procure inputs. NGOs and members of the donor community popularised the keyhole garden concept in a bid to provide support to the vulnerable in poor rural communities. NGOs provide inputs and farming implements to the supported households. This explains why access to inputs is significant in this study.

\section{CONCLUSIONS AND RECOMMENDATIONS}

The results of the study have shown that keyhole gardens contribute meaningfully to increased food security of participants in the study area. These gardens can be a source of vegetable nutrition and a source of income all year round. Donation of inputs significantly influences the food security status of households participating in keyhole gardens in the study area. Since keyhole gardens produce at a limited scale, efforts should target increased production by improving on the current model and concept where possible. The main issue of concern, however, is that the scalability and sustainability of keyhole garden programmes are uncertain given that virtually all keyhole garden production programs have been implemented by non-governmental organisations (NGOs). NGO staff are in most cases well trained and highly motivated to ensure the successful implementation of the program. It is, therefore, necessary that, for future upscaling programs in poor rural African countries, public officials should receive necessary training so that the keyhole garden project has the same impacts as it has had under NGOs. It is necessary to promote climate-smart gardens, such as keyhole gardens, to rural farmers to increase the rate of uptake, since production can be conducted throughout the year. The Government should implement relevant strategies and policies to improve rural farmers' livelihood, which in turn will contribute to the food security of rural households. Furthermore, the government should offer more support to homestead garden initiatives since they contribute to food and nutrition security.

Rural communities need to be encouraged to educate their youth, which can improve their knowledge and skills with the potential to boost their income-generating capacity. The poor level of education makes them redundant since they have no skills to secure formal employment that could provide them with non-farm income which they could invest in farming. Youth have no interest in farming, however, since there are no barriers to keyhole gardens, youth should be encouraged to participate so that they contribute towards the food security of their families. The study concluded that donations significantly influence the food security status of rural households. This is worrying as it exposes a significant 'donor dependency syndrome' of rural communities. Rural households need to be empowered to ensure that the fate of their food security status is in their hands. Access to inputs and market information in this study positively influenced food security status. Government should promote agribusiness initiatives along the value chain, as this would improve access to affordable inputs that would influence production and, ultimately, food security. Furthermore, access to market information improves the chances of farmers to successfully market their produce, with the expectation of achieving by farmers of improved income- and food-security status.

\section{REFERENCES}

Abbasi, S.S., Marwat, N.K., Naheed, S., Siddiqui, S. (2014). Food security issues and challenges: a case study of potohar. Eur. Acad. Res., 2(3), 3090-3113.

Abdullah, D.Z., Tariq, S., Sajjad, A., Waqar, A., Izhar, U.D., Aasir, I. (2019). Factors affecting household food security 
in rural northern hinterland of Pakistan. J. Saudi Soc. Agric. Sci., 18, 201-210.

Allagbe, H., Aitchedji, M., Yadouleton, A. (2014). Genesis and development of urban vegetable farming in Republic of Benin. Int. J. Innov. App. Stud., 7(1), 123-133.

Alene, D.A., Manyong, V.M., Omanya, G., Mignouna, H.D., Bokanga, M., Odhiambo, G.D. (2008). Smallholder marketed surplus and input use under transactions costs: Maize supply and fertilizer demand in Kenya. Food Polic. 32(4), 318-328.

Amaza, P.S., Umeh, J.C., Helsen, J., Adejobi, A.O. (2006) Determinants and Measurements of Food Insecurity in Nigeria: Some Empirical Policy Guide, Annual Meeting, August 12-18, 2006, Queensland, Australia, International Association of Agricultural Economists.

Awasthi, K., Bhat, K.K. (2016). Higher Returns from Higher Education: Effects on Agricultural income. Econ. Polit. Week., 51(7), 76-78.

Bajwa, B.E., Aslam, M.N., Malik, A.H., Malik, A.M.(2015). Food security and socio-economic conditions of women involved in kitchen gardening in Muzaffargarh, Punjab, Pakistan. J. Env. Agric. Sci., 4, 1-5.

Billingsley, R., Mothunyane, M., Thabane, M., McLean, S. (2013). Lessons from Lesotho: how a "joined-up" approach, centred on keyhole gardens, is tackling linked issues of hunger, nutrition and poverty, in Hunger Nutrition Climate Justice A New Dialogue: Putting People at the Heart of Global Development. 15-16 April 2013. Dublin, Ireland, 95-98.

Bogale, A. (2012). Vulnerability of smallholder rural households to food insecurity in Eastern Ethiopia. Food Sec., $4(4), 581-591$

BOS (Bureau of Statistics) (2017). Agricultural Production Survey Crops. Kingdom of Lesotho. No.33 of 2017.

Carletto, G., Ruel, M., Winters, P., Zezza, A. (2015). FarmLevel Pathways to Improved Nutritional Status : Introduction to the Special Issue. J. Dev. Stud., 51(8), 945-957.

FAO (2010). Household Food Security and Community Nutrition. Retrieved May $6^{\text {th }} 2017$ from: http://www.fao.org/ householdfoodsecurity/V4807e/v4807e05.htm

FAO (2013). The State of Food Insecurity in the World. Retrieved July 23 2018 from: http://www.fao.org/docrep/018/i3458e/i3458e.pdf

FAO (2015). Africa's Renewed Partnership to End Hunger by 2025. Retrieved Nov 1st 2015 from: https://www.google. $\mathrm{com} /$ search?client $=$ firefox-b-d\&q $=$ Africa $\% \mathrm{E} 2 \% 80 \% 99 \mathrm{~s}+$ Renewed+Partnership+to+End+Hunger+by +2025

FAO (2018). Food and Agricultural Organization of the United Nations. Lesotho Food Insecurity Access Scale in urban households in Iran. J. Pub. Health Nutr., 1-9.

Giannini, A., Biasutti, M., Held, I.M., Sobel, A.H. (2008). A global perspective on African climate. Clim. Change, 90, 359-383.
Girard, A.W., Self, J.L., McAuliffe, C., Olude, O. (2012). The Effects of Household Food Production Strategies on the Health and Nutrition Outcomes of Women and Young Children: A Systematic Review. Paediatr. Perinat. Epidem., 26(1), 205-222.

Gujarati, D.N. (2004). Basic Econometrics (4th ed.). McGrawHill Companies.

Haile, H.K., Alemu, Zerihun Gudeta, Kudhlande, G., (2005). Causes of household food insecurity in koredegaga peasant association, Oromiya zone, Ethiopia. Agrekon, 44(4), 543-560.

Harris-Fry, H., Azad, K., Kuddus, A., Shaha, S., Nahar, B., Hossen, M., Younes, L., Costello, A., Fottrell, E. (2015). Socio-economic determinants of household food security and women's dietary diversity in rural Bangladesh. J. Health Popul. Nutr., 33(2), 1-12.

Haselow, N.J., Stormer, A., Pries, A. (2016). Evidence-based evolution of an integrated nutrition- focused agriculture approach to address the underlying determinants of stunting'. Mater. Child Nutr., 12(1), 155-168.

Hernandez, R., Reardon, T., Guan, Z. (2010). Rural Nonfarm Employment and Agricultural Mechanization and Diversification in Guatemala. Paper presented at the Agricultural \& Applied Economics Association 2010 AAEA, CAES, \& WAEA Joint Annual Meeting, Denver, Colorado, July 25-27.

Ibnouf, F.O. (2011). Challenges and possibilities for achieving household food security in the Western Sudan region: the role of female farmers. J. Food Sec., 3(2), 215-231.

Iorlamen, T.R., Abu, G.A., Lawal, W.L. (2013). Comparative Analysis on Socio-economic Factors Between Food Secure and Food Insecure Households among Urban Households in Benue State, Nigeria. J. Agric. Sci., 4(2), 63-68.

Jha, A.K., Malla, R., Sharma, M., Panthi, J., Lakhankar, T., Krakauer, N.Y., Pradhanang, S.M., Dahal, P., Shrestha, M.L. (2016). Impact of irrigation method on water use efficiency and productivity of fodder crops in Nepal. Climate, 1(1)4, 1-13.

Kassie, M., Ndiritu, S.W., Stage, J. (2014). What determines gender inequality in household food security in Kenya? Application of exogenous switching treatment regression. World Dev., 56, 153-171.

Kingdom of Lesotho (2018). Lesotho Zero Hunger Strategic Review. Food and Nutrition Coordinating Office. Office of Prime Minister. Retrieved May 2019 from: https://reliefweb.int/report/lesotho/lesotho-zero-hungerstrategic-review-2018

Mango, N., Zamasiya, B., Makate, C., Nyikahadzoi, K., Siziba, S. (2014). Factors influencing household food security among smallholder farmers in the Mudzi district of Zimbabwe. Dev. South. Afr., 31(4), 625-640. 
Mango, N., Siziba, S., Makate, C. (2017). The impact of adoption of conservation agriculture on smallholder farmers' food security in semi-arid zones of Southern Africa. Agric. Food Sec., 6(32), 1-8.

Manju, K., Bhawana, M. (2014). Data Analysis of Students Marks with Descriptive Statistics. Int. J. Recent Inn. Trends Comput. Comm., 2(5), 1188-1190.

Mashinini, V. (2001) Managing communal vegetable production in Lesotho : the case of communal gardens. Africanus, 31(2), 6-16.

Masset, E., Haddad, L., Cornelius, A., Isaza-Castro, J. (2012). Effectiveness of agricultural interventions that aim to improve nutritional status of children: systematic review. Brit. Med. J., 344, 1-7.

Maziya, M., Mudhara, M., Chitja, J. (2017). What factors determine household food security among smallholder farmers? Insights from Msinga, KwaZulu-Natal, South Africa. Agrekon, 56(1), 140-152.

Mohsin, M., Anwar, M.M., Jamal, F., Ajmal, F., Breuste, J. (2017). Assessing the role and effectiveness of kitchen gardening toward food security in Punjab, Pakistan: A case ofdistrict Bahawalpur. Int. J. Urban Sust. Dev., 9(1), 64-78.

Nkosi, S., Gumbo, T., Kroll, F., Rudolph, M. (2014). Community gardens as a form of urban household food and income supplements in African cities: experiences in Hammanskraal. Africa: Africa Institute of South Africa Briefing, 112, 1-6.

Nwaneke, P.K., Chude, V.O. (2017). Are the Homestead Gardens a Possible Solution to Combating Malnutrition in Nigeria? Eur. J. Nutr. Food Safety, 7(4), 199-208.

Nyikahadzoi, K., Siziba, S., Mango, N., Mapfumo, P., Adekunhle, A., Fatunbi, O., (2012). Creating food self reliance among the smallholder farmers of eastern Zimbabwe: exploring the role of integrated agricultural research for development. Food Security, 4(4), 647-656.

Oduro-Ofori E, Aboagye A. P and Acquaye N. A. E. (2014). Effects of Education on the Agricultural Productivity of Farmers in the offinso municipality. Int. J. Dev. Res., 4(9), 1951-1960.

Olesen, J.E., Bindi, M. (2002). Consequences of climate change for European agricultural productivity, land use and policy. Eur. J. Agron., 16(4), 239-262.

Parry, M.L., Rosenzweig, C., Iglesias, A., Livermore, M., Fischer G. (2004). Effects of climate change on global food production under SRES emissions and socio-economic scenarios. Glob. Env. Change, 14(1), 53-67.

Paudel, B., Zhang, Y., Yan, J., Rai, R., Li, L. (2019). Farmers' perceptions of agricultural land use changes in Nepal and their major drivers. J. Env. Manag., 235, 432-441.

Quisumbing, A., Meinzen-Dick, R., Basset, L., Usnick, M., Pandolfelli, L., Morden, C., Alderman, H. (2008). Helping
Women Respond to the Global Food Price Crisis. IFPRI Policy Brief, 7, 1-4.

Ranasinghe, T.T. (2009) Manual of Low/No-Space Agriculture (L/N-SA) -Cum-Family Business Gardens (FBG). International Network of Resource Centres on Urban Agriculture and Food Security, RUAF Foundation,International Water Management Institute.

Rocchi, A., Del Sette, P. (2016). Lesotho: rural development and migration. Retrieved June $20^{\text {th }} 2020$ from: http://www. centrosaluteglobale.eu/site/wp-content/uploads/2016/05/ Migration-and-Rural-Development-in-Lesotho-PDF.pdf

Rose, D., Charlton, K.E. (2002). Prevalence of household food poverty in South Africa: Results from large representative survey. Publ. Health Nutr., 5(3), 383-389.

Roy, B., Rahman, H., Fardusi, J.M. (2013). Status, Diversity, and Traditional Uses of Homestead Gardens in Northern Bangladesh: A Means of Sustainable Biodiversity Conservation. Int. Scholar. Res. Not., 124103, 1-11.

Ruben, R., Chagwiza, C., Muradian, R. (2017). Knowledge systems and value chain integration: The case of linseed production in Ethiopia. J. Agric. Educ. Exten., 23(5), 443-449.

Ruel, M.T., Alderman, H. (2013). Nutrition-sensitive interventions and programmes: how can they help to accelerate progress in improving maternal and child nutrition? Lancet, 382(9891), 536-551.

Suvedi, M., Ghimire, R., Kaplowitz, M. (2017). Revitalizing agricultural extension services in developing countries: Lessons from off-season vegetable production in rural $\mathrm{Ne}$ pal. J. Int. Soc. Southeast Asian Agric. Sci., 23(1), 1-11.

Taiwo, A.O. (2015). The role of Gender and Psychosocial Factors on Perceived Vulnerability to HIV/AIDS Infection among Young and Middle Aged Adults in Benin City. J. Psychol. Psychother., 5(2), 1-8.

Twongyirwe, R., Mfitumukiza, D., Barasa, B., Naggayi, B.R., Odongo, H., Nyakato, V., Mutoni, G. (2019). Perceived effects of drought on household food security in South-western Uganda: Coping responses and determinants. Weather Clim. Extrem., 24, 1-11.

UNOCHA (2014). Lesotho Reference Map. Retrieved March 22nd 2021 from: https://www.humanitarianresponse. info/sites/www.humanitarianresponse.info/files/ROSA 1so_295v2_ref_map_A4_2014_02_27.pdf

Vitiello, D., Wolf-Powers, L. (2014). Growing food to grow cities? The potential of agriculture for economic and community development in the urban United States. Comm. Dev. J., 49(4), 508-523.

You, L., Ringler, C., Wood-Sichra, U., Robertson, R., Wood, S., Zhu, T., Nelson, G. Guo, Z., Sun, Y. (2015). What is the irrigation potential for Africa? A combined biophysical and socioeconomic approach, Food Pol., 36(6), 770-782. 